J. Clin. Chem. Clin. Biochem.

Vol. 14, 1976, pp. 225-226

\title{
A New Enzymatic Method for the Determination of Free and Conjugated Glucuronic Acid
}

\author{
By G. Wagner and S. Hollmann
}

Institut für Physiologische Chemie I der Universität Düsseldorf

(Received May 28, 1975/January 9, 1976)

Summary: A new method is reported for the quantitative determination of glucuronic and galacturonic acid, which is based on the spectrophotometric measurement of NADH. The NAD-linked oxidation of the uronic acids to the corresponding dicarboxylic acids is measured in the presence of uronic acid dehydrogenase. This enzyme was isolated from Pseudomonas syringae. The test is highly specific for glucuronic and galacturonic acid and permits the exact determination of free and conjugated glucuronic acid. This enzymatic determination of glucuronic acid is the most sensitive method available today.

\section{Neue enzymatische Methode zur Bestimmung freièr und konjugierter Glucuronsäure}

Zusammenfassung: Es wurde eine neue Methode zur quantitativen Bestimmung von Glucuron- und Galakturonsäure mit Hilfe des optischen Tests entwickelt. Die NAD-gebundene Oxidation der Uronsäuren zu den entsprechenden Dicarbonsäuren wird in einer durch Uronsäure-Dehydrogenase katalysierten Reaktion gemessen. Das Enzym wurde aus Pseudomonas syringae isoliert. Der Test ist sehr spezifisch für Glucuron- und Galakturonsäure. Mit ihm kann freie und konjugierte Glucuronsäure genau bestimmt werden. Im Augenblick ist diese enzymatische Methode die empfindlichste Methode zur quantitativen Glucuronsäurebestimmung.

\section{Introduction}

Methods as yet available for the determination of glucuronic acid are based on the carbazole reaction of Dische (1). Various modifications of this colour reaction with higher sensitivity were summarized by Marsh (2). These tests have certain disadvantages; they are not specific, and they are subject to interference by various compounds, they are also time-consuming, and they do not differentiate between free and conjugated glucuronic acid. A less sensitive method using gas chromatography was described by Inoue (3). Until now, a specific enzymatic method for glucuronic acid determination was lacking.

This paper describes a new method for the quantitative determination of glucuronic and galacturonic acid which is based on the $\mathrm{NAD}^{+}$-linked enzymatic oxidation of these uronic acids to the corresponding dicarboxylic acids with the stoichiometric formation of NADH:

$$
\begin{gathered}
\text { glucuronic acid } \\
+\mathrm{NAD}+\underset{\text { galonic acid }}{\stackrel{\text { dehydrogenase }}{\text { mucic acid }}}
\end{gathered}+\mathrm{NADH}+\mathrm{H}^{+}
$$

The uronic acid dehydrogenase was discovered in the phytopathogenic bacterium Pseudomonas syringae (4) and purified and characterized $(5,6)$. The values ob- tained are identical for both uronic acids. In the presence of both uronic acids the galacturonic acid content can be determined according to Nagel (7) and subtracted from the total content determined by the uronic acid dehydrogenase test. The main interest of this study was the development of a sensititve glucuronic acid assay for samples containing only free and/or conjugated glucuronic acid.

\section{Materials and Methods}

D-glucuronic acid grade I (Sigma, St. Louis, Missouri, USA) and $D$-galacturonic acid (Serva, Heidelberg, FRG) may contain an unknown amount of water. Before use as standards they were dried to constant weight at $50^{\circ} \mathrm{C}$ under vacuum in a rotation evaporator. Phenolphthalein- $\beta-D$-glucuronide sodium salt, and $p$-nitrophenyl $-\beta$ - $D$-glucuronide (Serva), testosterone- $\beta$ - $D$-glucuronide sodium salt, chromatographically pure was obtained from C. Funke, Düsseldorf, NAD grade I, and $\beta$-glucuronidase from $E$. coli $\mathrm{K} 12$ ( $\beta-D$-Glucuronide glucuronosohydrolase EC 3.2.1.31) about $100 \mathrm{kU} / 1$ (Boehringer, Mannheim, FRG). Uronic acid dehydrogenase (Uronate: NAD 1-oxidoreductase EC 1.2.1.35) from Pseudomonos syringae ATCC 13394 was isolated from cells grown on glucuronic acid according to Wagner (6). For quantitative glucuronic acid determination, the enzy me fraction after Sepliadex G-100 chromatography containing $25-30 \mathrm{kU} / \mathrm{l}$ was used. All other reagents were analytical grade (Merck, Darmstadt, FRG). 
Determination of free glucuronic acid

The reaction mixture of $1.1 \mathrm{ml}$, in a cuvette with $1 \mathrm{~cm}$ light path, consists of $82 \mathrm{mmol} / 1$ sodium diphosphate-HCl-buffer pH 8.0, $0.9 \mathrm{mmol} / 1 \mathrm{NAD}$, and the sample to be determined containing 2 to $95 \mu \mathrm{mol} / 1$ glucuronic acid. The reaction is started by the addition of $0.1 \mathrm{ml}$ uronic acid dehydrogenase solution (about $2.5 \mathrm{U}$ ) and run at $25^{\circ} \mathrm{C}$ for $30 \mathrm{~min}$. Absorbance is read at $334 \mathrm{~nm}$ against a reagent blank in an Eppendorf photometer (Hamburg, FRG). Glucuronic acid is determined with the aid of a standard curve from the difference between the absorbances at the beginning and end of the incubation.

$\beta$-glucuronidase cleavage

For cleavage, the reaction mixture of $1 \mathrm{ml}$, which consists of $50 \mathrm{mmol} / 1 \mathrm{Na}-\mathrm{K}$-phosphate buffer, $\mathrm{pH} 7.0, \beta$-glucuronidase (about $2.5 \mathrm{U}$ ) and the sample with a maximal glucuronide concentration of $0.5 \mathrm{mmol} / \mathrm{l}$ is incubated for $30 \mathrm{~min}$ at $37^{\circ} \mathrm{C}$.

\section{Combined cleavage and determination}

The test, volume $1.1 \mathrm{ml}$, consists of $75 \mathrm{mmol} / \mathrm{l}$ sodium diphosphate-HCl-buffer, pH 8.0, $0.9 \mathrm{mmol} / 1 \mathrm{NAD}^{+}$, about $2.5 \mathrm{U}$ of uronic acid dehydrogenase and the sample with up to $60 \mu \mathrm{mol} / 1$ glucuronide. Absorbance 1 is measured at $334 \mathrm{~nm}$ against a blank without glucuronide. The reaction is started with $\beta$-glucuronidase (about $2.5 \mathrm{U}$ ) and incubated at $25^{\circ} \mathrm{C}$. Absorbance 2 is read after $30 \mathrm{~min}$.

\section{Determination of coloured aglycons}

After cleavage, the sample is diluted with $0.5 \mathrm{~mol} / 1$ glycine$\mathrm{NaOH}$-buffer, $\mathrm{pH}$ 10.5. Phenolphthalein is measured at $546 \mathrm{~nm}$ $(\epsilon=29600 \mathrm{l} / \mathrm{mol} \cdot \mathrm{cm}), p$-nitrophenol at $405 \mathrm{~nm}(\epsilon=18500$ $1 / \mathrm{mol} \cdot \mathrm{cm})$.

\section{Results and discussion}

In the enzymatic method for glucuronic acid, the NADH absorbance is proportional to the glucuronic acid concentration according to Lambert-Beer's law, in the range 0.5 to $20 \mu \mathrm{g}$ glucuronic acid per test, with a deviation less than $3 \%$. The glucuronic acid content should be estimated from a standard curve, because the theoretical value calculated from NADH absorbance is about $10 \%$ higher.

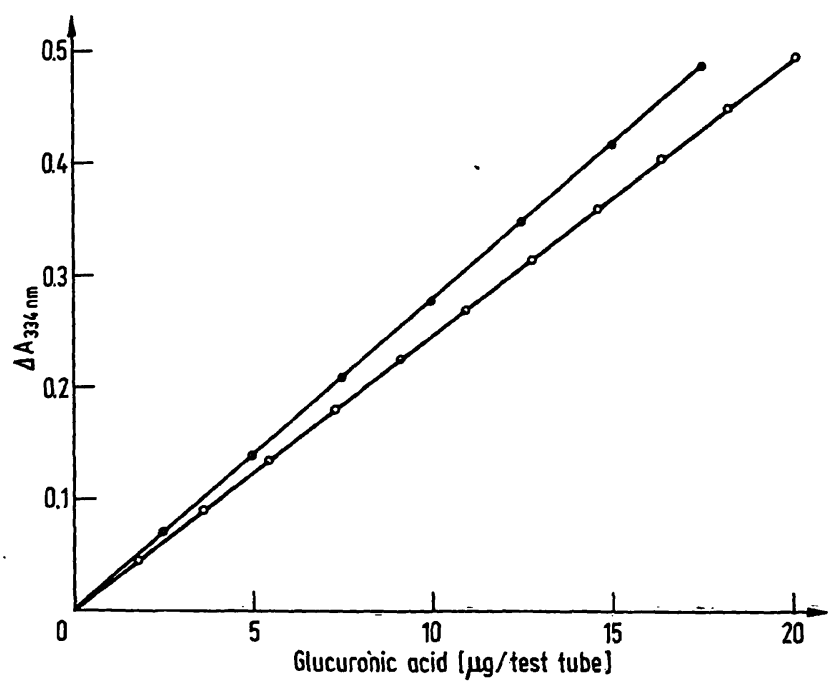

Fig. 1. Optical test for glucuronic acid based on the spectrophotometric determination of NADH: experimental curve (open circles), curve calculated from NADH absorbance (closed circles).
Each test should contain excess of NAD, because uronic acid dehydrogenase is competitively inhibited by NADH (6). Since only free uronic acid is attacked by uronic acid dehydrogenase, $\beta$-glucuronides must be hydrolyzed by $\beta$-glucuronidase treatment before determination:

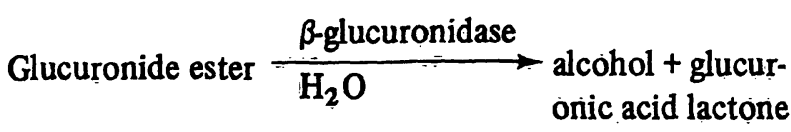

The resulting lactone is spontaneously transformed to glucuronic acid at the alkaline $\mathrm{pH}$ of the optical test.

The enzymatic test was used for the determination of glucuronic acid in $p$-nitrophenyl glucuronide, phenolphthalein glucuronide and testosterone glucuronide. After cleavage $p$-nitrophenol and phenolphthalein were determined photometrically, a comparison between the aglycon and glucuronic acid showed for both compounds tested a deviation of less than $3 \%$. This method permits the quantitative estimation of aglycons that are difficult to determine, e. g. in steroid glucuronides, by determination of their glucuronic acid content. The method can be simplified for $\beta$-glucuronides whose aglycons do not absorb at $334 \mathrm{~nm}$ under test conditions. In this case cleavage and determination can be coupled, thus yielding a quicker method of higher precision.

The described enzymatic method permits the quantitative and highly specific dêtermination of glucuronic acid. This simple and rapid method is the most sensitive available today. In contrast to former methods, the present test permits the separate determination of free and conjugated glucuronic acid, by performing the determination before and after cleavage. The use of this method in metabolic studies will be the subject of further investigation.

\section{Acknowledgement}

We thank Mrs. Anna Maria Unterreiner for skillful technical help.

\section{References}

1. Dische, Z. (1947), J. Biol. Chem. 167, 189-198.

2. Marsh, C. A. (1966), in Glucuronic acid free and combined (Dutton, G. J. ed.) pp. 26-32, Academic Press, New York and London.

3. Inoue, S. (1973), Biochim. Biophys. Acta 329, 264-270.

4. Kilgore, W. W. \& Starr, M. P. (1959), Nature (London) $183,1412-1413$.

5. Bateman, D. F., Kosuge, T. \& Kilgore, W. W. (1970), Arch. Biochem. Biophys. 136, 97-105.

6. Wagner, G. \& Hollmann, S. (1976), Eur. J. Biochem., 61, 589-596.

7. Nagel, C. W. \& Hasegawa, S. (1967), Anal. Biochem. 21, $411-415$.

\author{
Dr. G. Wagner \\ Institut für Physiologische Chemie I \\ Universität Diisseldorf \\ Moorenstr. 5 \\ D-4000 Düsseldorf
}

